\title{
Barley Rom1 Reveals a Potential Link Between Race-Specific and Nonhost Resistance Responses to Powdery Mildew Fungi
}

\author{
Andreas Freialdenhoven, ${ }^{1}$ James Orme, ${ }^{2}$ Thomas Lahaye, ${ }^{3}$ and Paul Schulze-Lefert ${ }^{1}$ \\ ${ }^{1}$ Max-Planck Institut für Züchtungsforschung, Carl-von-Linné-Weg 10, D-50829 Köln, Germany; ${ }^{2}$ The Sainsbury Laboratory, \\ John Innes Centre, Colney Lane, Norwich NR4 7UH, U.K.; ${ }^{3}$ Institut für Genetik, Martin-Luther-Universität Halle-Wittenberg, \\ Weinbergweg 10, D-06120 Halle (Saale), Germany
}

Submitted 30 September 2004. Accepted 21 December 2004.

The Rarl gene, identified in the context of race-specific powdery mildew resistance mediated by the Hordeum vulgare (barley) resistance $(R)$ gene Mla12, is required for the function of many $R$-mediated defense responses in monoand dicotyledonous plant species. Mla resistance is associated with an oxidative burst and a subsequent cell death reaction of attacked cells. Rar1 mutants are impaired in these responses and, to identify genetic elements which negatively regulate the Mla12-triggered response, we have screened mutagenized Mla12 rar1 mutant populations for restoration of the resistance response. Here we describe the restoration of Mla12-specified resistance (rom1) mutant that restores features of disease resistance to a Blumeria graminis f. sp. hordei isolate expressing the avirulence gene AvrMla12 and retains susceptibility to an isolate lacking AvrMla12. Histochemical analyses show that, in rom1 mutant plants, a whole-cell oxidative burst and cell death response in attacked epidermal cells is restored in the incompatible interaction. Defense responses against tested inappropriate powdery mildews, $B$. graminis f. sp. tritici and Golovinomyces orontii, were diminished in rarl mutant plants and enhanced in rom 1 mutant plants relative to the wild type. These findings indicate antagonistic activities of Rarl and Rom1 and reveal their contribution to nonhost and race-specific resistance responses.

Additional keywords: negative regulator, pathogen resistance, suppressor screen.

Plants have evolved different levels of resistance to defend themselves against pathogen attack (Dangl and Jones 2001). The most common defense renders an entire plant species resistant to a specific pathogen and is known as nonhost resistance (Mysore and Ryu 2004). Nonhost resistance is the most durable form of resistance and is thought to be genetically complex, involving preformed and inducible defenses. Insights into its genetic components were laid by the cloning of genes NHOI and PEN1 in Arabidopsis thaliana involved in resistance to the bacterium Pseudomonas syringae and the grass powdery mildew Blumeria graminis f. sp. hordei, respectively (Collins et al. 2003; Kang et al. 2003). NHOl encodes a glycerol kinase but its precise function during resistance is

Corresponding author: A. Freialdenhoven; E-mail: freiald@ freenet.de

Current address of A. Freialdenhoven: David-Hansemann-Realschule, Sandkaulstrasse 12, 52062 Aachen, Germany. still unknown. PENl encodes a syntaxin and is supposed to have a role in mediating fusion of vesicles containing toxic cargo at the plasma membrane during attempted fungal invasion into leaf epidermal cells. A mutation in the PEN1 homolog in barley, Ror2, originally was identified as suppressor of another form of pathogen resistance termed non-race-specific resistance or broad spectrum resistance against virulent isolates of $B$. graminis f. sp. hordei (Freialdenhoven et al. 1996). Broad spectrum B. graminis f. sp. hordei resistance in barley is conferred by loss-of-function alleles ( $\mathrm{mlo}$ ) of Mlo (Büschges et al. 1997). The finding that A. thaliana PEN1 and barley ROR2 are functionally homologous syntaxins points to the existence of shared molecular components in broad-spectrum and nonhost resistance responses in monoand dicotyledonous plant species.

Plants have the capacity to recognize pathogen-derived molecules or structures that are either conserved in multiple microbial species or occur in one or few pathogen isolates (Nürnberger et al. 2004). Recognition of the former is mediated by membrane-resident receptors such as Arabidopsis FLS2 (Gómez-Gómez and Boller 2000) and mutations in the corresponding gene were shown to result in enhanced disease susceptibility (super-susceptibility) to virulent $P$. syringae (Zipfel et al. 2004). Recognition of isolate-specific pathogen effectors is mediated either by membrane-resident or intracellular race-specific resistance $(\mathrm{R})$ proteins (Bonas and Lahaye 2002). Most isolated $R$ genes encode intracellular proteins containing a nucleotide-binding (NB) domain and C-terminal leucine-rich repeats (LRRs). Isolate-specific effectors, recognized by $\mathrm{R}$ proteins, are encoded by so-called avirulence (Avr) genes (Flor 1971). Currently, much research is being undertaken to unravel the molecular mechanics of effector recognition (direct or indirect) and to understand downstream events triggered by $R$ genes. Mutational analyses uncovered genes required for $R$ gene function in a number of plant-microbe interactions (Freialdenhoven et al. 1994; Hammond-Kosack et al. 1994; Salmeron et al. 1994). Among these was the Rarl gene in barley, which originally was shown to be required for racespecific resistance triggered by the NB-LRR type $\mathrm{R}$ protein MLA12 toward B. graminis f. sp. hordei isolates containing AvrMla12 (Freialdenhoven et al. 1994; Shen et al. 2003; Torp and Jørgenson 1986).

Rarl encodes an intracellular $\mathrm{Zn}^{2+}$-binding protein (Shirasu et al. 1999) and subsequent analyses has shown that RAR1 is required for several $R$-gene-mediated responses against different pathogen classes in monocotyledonous and dicotyledonous plant species (Shirasu and Schulze-Lefert 2003). RAR1 is re- 
quired for the function of two subtypes of NB-LRR proteins, which differ from each other by the presence of a coiled-coil (CC) or a Toll and Interleukin-1 receptor (TIR)-like domain at the $\mathrm{N}$ terminus. This is in contrast to other identified components required for $R$ gene function such as EDS1 and NDRl, which appear to be preferentially engaged by either the TIRNB-LRR or the CC-NB-LRR subclasses (Aarts et al. 1998; Century et al. 1997, Falk et al. 1999). Barley RAR1 interacts in yeast and in vivo with SGT1, an intracellular protein that, similar to RAR1, is also required for a number of resistance responses triggered by both NB-LLR R protein subclasses in diverse plant species (Azevedo et al. 2002; Shirasu and Schulze-Lefert 2003). The biochemical roles of RAR1 and SGT1 in NB-LRR-mediated resistance are poorly understood. However, physical association of RAR1 with cytosolic HSP90 and structural features in plant SGT1 and animal RAR1 homologs that resemble co-chaperones have led to the idea that these proteins might either alone or together exert cochaperonelike activities in the folding of $\mathrm{R}$ protein containing recognition complexes or downstream signaling complexes (Hubert et al. 2003; Liu et al. 2004; Takahashi et al. 2003). Consistent with this is the observation that the abundance of the Arabidopsis NB-LRR RPM1 protein is drastically reduced in nonchallenged rarl mutant plants (Tornero et al. 2002). Interestingly, gene silencing experiments in Nicotiana benthamiana suggest that SGT1 and cytosolic HSP90 contribute to nonhost resistance responses, indicating a potential link between racespecific resistance and nonhost resistance (Kanzaki et al. 2003; Peart et al. 2002).

The barley Mla $R$ locus is highly polymorphic and encodes more than 28 characterized race-specific resistance specificities to B. graminis f. sp. hordei isolates (Jørgensen 1994; Wei et al. 2002). Molecular isolation of Mla1, Mla6, Mla7, Mla10, Mla12, and Mla13 suggest that these might be alleles of one of several NB-LRR $R$-gene homologs at Mla (Halterman and Wise 2004; Halterman et al. 2001; Shen et al. 2003; Wei et al. 2002; Zhou et al. 2001). Despite the high sequence identity of the molecularly isolated Mla $R$-gene specificities (>90\%), only a subset of MLA proteins engage RAR1 for efficient resistance (Jørgenson 1996). MLA chimeras have been generated in which AvrMla6 recognition specificity was uncoupled from RAR1 dependence (Shen et al. 2003) and a single amino acid substitution in the LRR domain alleviates RAR1 dependence of Mla6 and Mla13 resistance reactions (Halterman and Wise 2004). These data demonstrate that subtle changes in MLA proteins can affect RAR1 engagement in race-specific resistance and might indicate a physical activity close to MLA. The resistance response triggered by Mla $R$-gene specificities invariably is linked to a cell death reaction of the attacked epidermal host cell and few subtending mesophyll cells (hypersensitive response; HR) (Boyd et al. 1995). In susceptible Mla12 rarl mutant plants, both Mla12triggered host cell death and a preceding whole-cell oxidative burst, that may serve as a signal for race-specific resistance responses (Hückelhoven and Kogel 2003), is severely impaired (Shirasu et al. 1999).

The objective of this work was to uncover presumptive negative control elements of race-specific resistance triggered by Mla12. We made a suppressor screen based on the assumption that the impaired resistance response in susceptible Mla12 rarl mutant plants can be restored by the removal of negative regulators and identified a mutant, roml, that shows restoration of Mla12-mediated resistance responses. Altered nonhost defense responses to two tested inappropriate powdery mildew species in rarl and roml mutant plants led us to propose that the corresponding wild-type genes might have a dual role in both race-specific and nonhost resistance.

\section{RESULTS}

Seed of both the rarl-1 mutant M82 and the rarl-2 mutant M100 (Freialdenhoven et al. 1994) were mutagenized with $\mathrm{NaN}_{3}$, and approximately 4,000 independent $\mathrm{M}_{2}$ families comprising approximately $50,000 \mathrm{M}_{2}$ seedlings were screened for a modified infection phenotype upon inoculation with the AvrMla12-containing powdery mildew isolate A6. In all, 152 putative mutants were selected and classified into three classes with respect to a modified infection phenotype compared with the corresponding susceptible rarl mutant. The first class consisted of four candidates with a fully resistant infection phenotype, likely to be putative mlo mutants. Into the second class we grouped 85 candidates displaying enhanced disease resistance to the powdery mildew infection, and the last class contained 63 candidates with a lesion mimic phenotype prior to inoculation. Eighty-nine candidates survived to produce $\mathrm{M}_{3}$ seed. We focused on mutants of the second class and reduced the total number of candidates to seven by further inoculation tests. Here we will give a detailed phenotypic and genetic description of the first mutant of this class. The remaining mutants will be described elsewhere.

\section{Enhanced disease resistance to $B$. graminis f. $\mathbf{s p .}$ hordei.}

In order to verify that mutant $348 / 1$ a originated from the rarl-2 mutagenized $\mathrm{M}_{2}$ population, we performed a fingerprint analysis with cleaved amplified polymorphic sequence (CAPS) markers that previously were used for high-resolution mapping of the Rarl locus (Lahaye et al. 1998). In addition, mutant 348/1a displayed a characteristic anthocyanin deficiency in the leaf sheath, a phenotype that is diagnostic for Sultan5, the barley cultivar in which the mutant population was generated (Freialdenhoven et al. 1994). Thus, our analyses ensured that the identified mutant line was not due to seed contamination. The infection phenotypes of the Mla12-resistant wild type, the rarl-2 mutant, and mutant 348/1a upon inoculation with the AvrMla12-containing isolate A6 is shown in Figure 1. In Mla12 Rarl-resistant wild-type plants, only small necrotic lesions but no sporulating colonies were visible (Fig. 1A). In the rarl-2 mutant, resistance was impaired and the inoculated primary leaves were covered by fungal mycelium (Fig. 1B). In mutant 348/1a, the number of sporulating colonies was drastically reduced, and this was accompanied by a necrotic response (Fig. 1C). Notably, the necrotic response was much stronger than in resistant wild-type Sultan5. At a later stage of the infection, the necrosis in mutant 348/1a often led to the collapse of the inoculated primary leaf, a phenotype that is not observed in Sultan5. However, progeny of the new mutant grown under pathogen-free conditions (not shown) and leaf tissue protected with tape prior to inoculation (Fig. 1D) did not show a spontaneous or spreading necrosis, indicating that lesions result only upon powdery mildew attack.

In order to test whether the new infection phenotype was due to a mutation in host factors that are required for powdery mildew fungi to fulfill their life cycle, we inoculated mutant 348/1a with the virulent powdery mildew isolate K1 that lacks AvrMla12. Mutant 348/1a was fully susceptible (Fig. 1E). The mutant also was fully susceptible to another biotrophic fungus, a virulent yellow rust isolate that colonizes mesophyll tissue (Puccinia graminis f. sp. hordei) (Fig. 1F). Thus, mutant 348/1a supports unrestricted growth of two tested virulent biotrophic fungi but is affected in the Mla12triggered race-specific resistance response. In accordance to the observed infection phenotype in mutant 348/1a, we designated the corresponding wild-type locus "restoration of Mla12-specified resistance" (Roml) and refer to mutant $348 / 1$ a as the rom 1 mutant plant. 
Restored pathogen triggered whole-cell $\mathrm{H}_{2} \mathrm{O}_{2}$ accumulation and cell death in the rom 1 mutant.

Barley rarl mutant plants are impaired in two commonly observed race-specific resistance responses, accumulation of reactive oxygen species and cell death of attacked epidermal cells (Shirasu et al. 1999); therefore, we compared wild-type (WT) (Mla12 Rarl Rom1), rarl-2 mutant (Mlal2 rarl-2 Rom 1), and rom 1 mutant plants (Mlal2 rarl-2 rom l) in a time course experiment for the above-described cytological reactions upon infection with the fungal isolate A6 (AvrMla12). The results are summarized in Figure 2.

Staining with 3,3'-diaminobenzidine (DAB), which allows detection of $\mathrm{H}_{2} \mathrm{O}_{2}$, did not uncover genotype-specific differences at an early stage of the interaction $(24 \mathrm{~h}$ postinoculation [hpi]) where DAB staining is restricted mainly to cell wall appositions (CWAs) underneath sites of attempted fungal penetration (not shown). At 48 hpi, the fungus had penetrated epidermal host cells in up to $60 \%$ of interaction sites in all three genotypes (Fig. 3). Detection of DAB polymerization showed similar whole-cell accumulation of $\mathrm{H}_{2} \mathrm{O}_{2}$ for wild-type and roml mutant plants (Fig. 2A and C). In contrast, the rarl-2 mutant essentially lacked DAB wholecell staining despite the presence of fully developed fungal haustoria (Fig. 2B). No DAB whole-cell staining was detected in the Rarl wild-type, rarl-2, and roml mutant plants when being inoculated with the virulent fungal isolate $\mathrm{K} 1$, which lacks AvrMla12 (not shown).

The Rarl wild-type, rarl-2, and roml mutant plants also were studied by trypan blue, a stain that marks cells that are committed to die (Koegh et al. 1980). In Rarl wild-type plants, clusters of stained mesophyll cells were visible at 72 hpi and hyphal growth of the fungus ceased (Fig. 2D). In the rarl-2 mutant, trypan blue was rarely detectable in attacked host cells indicative of an impaired cell death reaction (Fig. 2E). In contrast, the rom 1 mutant plants showed trypan blue staining in attacked epidermal host cells (Fig. 2F). At 96 hpi, trypan blue also became visible in mesophyll cells. This reaction might lead to the severe necrotic infection phenotype 7 days postinoculation. Taken together, our data demonstrate that, in contrast to rarl mutant plants, in roml mutant plants both typical cytological events of race-specific resistance are reinstated: generation of reactive oxygen species and cell death in host cells that are attacked by $B$. graminis f. sp. hordei.

\section{Rom1 dependent resistance kinetics.}

The kinetics of the Mla12-triggered resistance response can be changed by Mla12 over-expression from a slow post-penetration to a rapid pre-penetration resistance in a transient single-cell gene expression system. Despite its altered kinetics, this altered Mla12 resistance response retains its requirement for Rarl (Shen et al. 2003). We have investigated roml mutant plants using this transient test system (Fig. 3).

Penetration frequencies were measured as the formation of a fully developed haustorium in attacked epidermal host cells, which were marked by $\beta$-glucuronidase staining to monitor transformation efficiency. Delivery of an empty vector resulted in approximately $60 \%$ fungal penetration in all three genotypes after inoculation with isolate A6 (AvrMla6 and AvrMla12). This demonstrates that neither rarl nor roml mutant plants interfere with the ability of B. graminis $\mathrm{f}$. $\mathrm{sp}$. hordei to switch from surface to invasive growth. Bombardment with the Mla12 over-expression construct reduced the amount of successful penetration in wild-type plants to approximately $5 \%$. This shift of the resistance kinetics is Rarl dependent, as shown by an unaltered high-penetration frequency (approximately 60\%) in the rarl-2 mutant. However, in the rom 1 mutant, an intermediate penetration frequency of approximately $37 \%$ was obtained ( $\chi^{2}$ test, $P<0.05$ compared with the rarl-2 mutant). Therefore, we conclude that, in a rarl-2 mutant background, roml plants (genotype Mla12 rarl-2 rom 1) partially restore the ability to shift the resistance kinetics upon Mla12 over-expression.

In order to test whether, in rom 1 mutant plants, the Rarldependent Mla6-triggered defense response (Halterman et al. 2001) is affected, we conducted bombardment experiments using an Mla6 over-expression construct. In the wild type, no fungal penetration into bombarded cells was detected, a typical feature of the rapid pre-penetration resistance response triggered by Mla6. Dependence of the response on Rarl was detected by $10 \%$ haustorium formation in the rarl-2 mutant. Although, in rom 1 plants, the penetration frequency appeared to be reduced compared with $\operatorname{rarl-2}$ plants $(7.5 \%)$, this reduction was statistically insignificant. Control experiments with the Rarl-independent Mlal gene (Zhou et al. 2001) and the powdery mildew isolate $\mathrm{K} 1$ (AvrMlal) resulted in early termination of fungal growth prior to haustorium formation in all three tested genotypes (not shown).
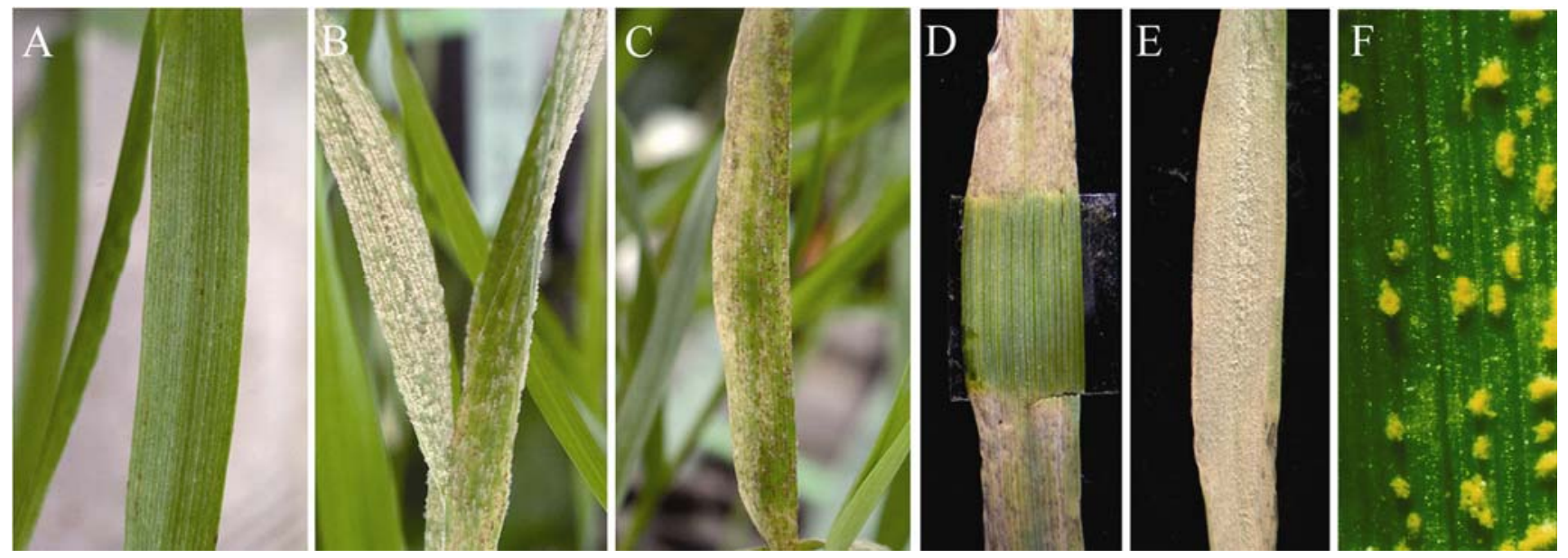

Fig. 1. Infection phenotypes of wild-type and mutant plants. Infection phenotype of A, wild-type Sultan5 (Mla12 Rar1 Rom1), B, rar1 mutant M100 (Mla12 rarl-2 Rom1), and C, roml mutant 348/1a (Mla12 rarl-2 roml) 7 days after inoculation with powdery mildew isolate A6 (AvrMla12). D, Restriction of necrosis to powdery mildew-attacked tissue in the rom 1 mutant. E, Full susceptible infection phenotype of the rom 1 mutant 7 days after inoculation with virulent powdery mildew isolate K1. F, Full susceptible infection phenotype of the rom 1 mutant 14 days after inoculation with virulent yellow rust isolate JIW28. 


\section{Rom1 is involved in nonhost defense responses.}

We previously have shown that an HR-like cell death response is triggered in barley by inoculation with the wheat powdery mildew (B. graminis f. sp. tritici) isolate JIW28 (Peterhänsel et al. 1997). Therefore, we investigated the reaction of the wild type (Mla12 Rarl Rom1), rarl-2 (Mla12 rarl2 Roml), and roml (Mla12 rarl-2 roml) mutant upon inoculation with isolate JIW28. No colony formation was observed in any of the genotypes tested. Inspections under UV light revealed whole-cell autofluorescence in the wild type indicative of a pathogen-induced cell death response (Fig. 4A). The response was drastically reduced in the rarl-2 mutant background (Fig. 4B). In contrast, inoculated roml mutant plants showed a hyper-autofluorescence of attacked tissue, which was significantly stronger compared with the wild type (Fig. 4C). Microscopic evaluation of infection sites revealed that in no case had the fungus penetrated barley epidermal cells (not shown). However, staining of the specimen with aniline blue and inspection under UV showed that, in wild-type Sultan5 and roml plants, whole-cell deposition of callose occurred in response to fungal attack which, in the case of roml plants, was spreading into the mesophyll layer (Fig. 4G and I). In the rarl-2 mutant, this reaction was restricted mostly to CWAs underneath fungal appressoria (Fig. 4E and H). Importantly, we obtained a comparable result in inoculation experiments using the inappropriate powdery mildew species Golovinomy-

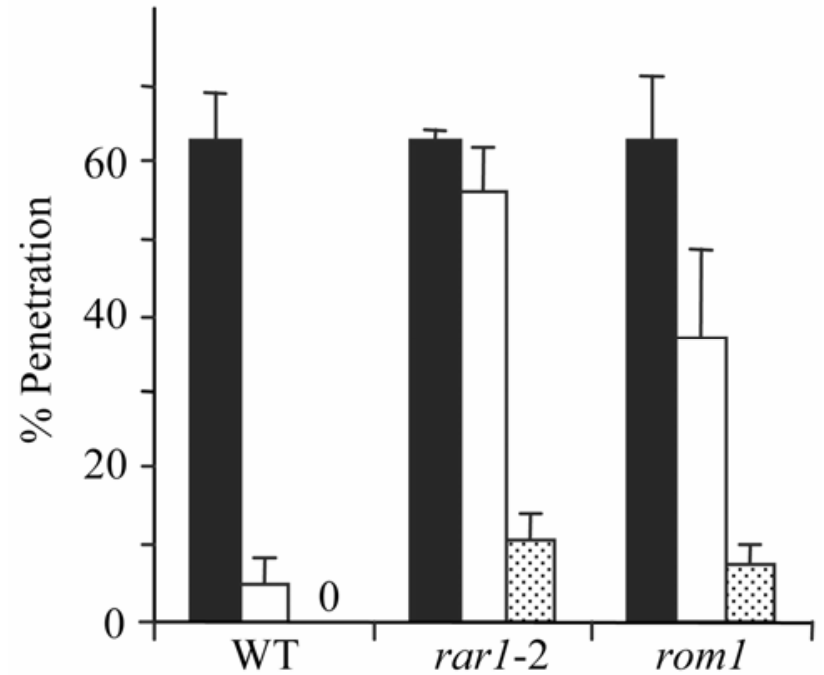

Fig. 3. Haustorium formation of powdery mildew in epidermal cells of barley. Mean values of developed haustoria in single epidermal cells of wild-type Sultan5 (WT; Mla12 Rar1 Rom1), rar1-2 mutant (Mla12 rar1-2 Rom1), and rom1 mutant (Mla12 rarl-2 rom1). Detached barley leaves were bombarded with a $\beta$-glucuronidase reporter construct together with an empty vector (black bars) or a construct over-expressing the resistance gene Mla12 (white bars) or Mla6 (dotted bars) under transcriptional control of the maize ubiquitin promoter.

\section{WT}
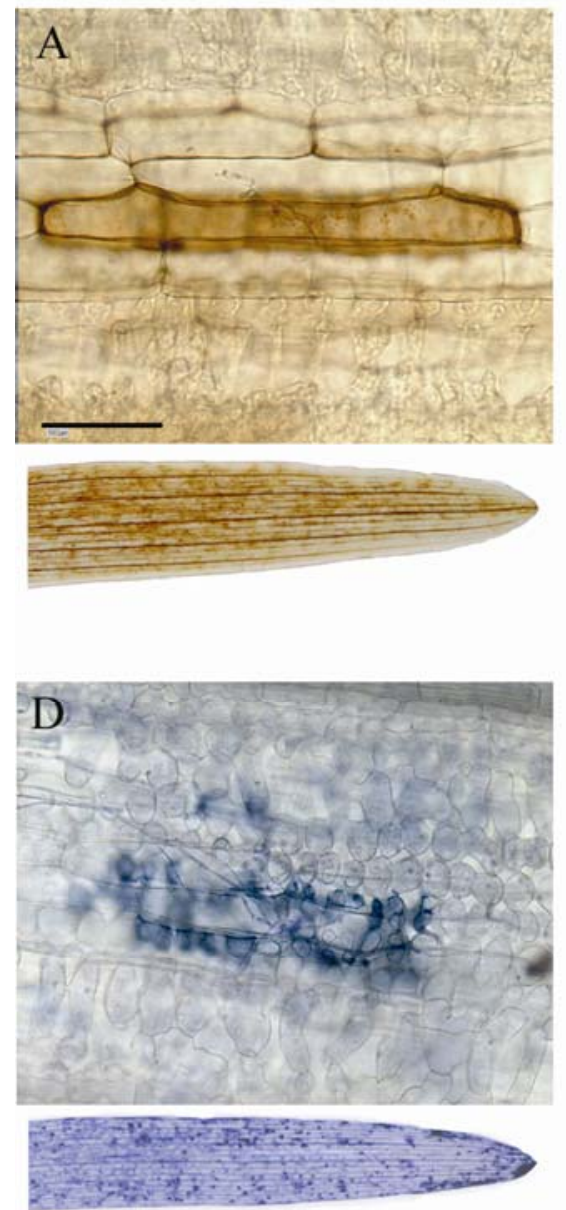

$\operatorname{rar} 1-2$
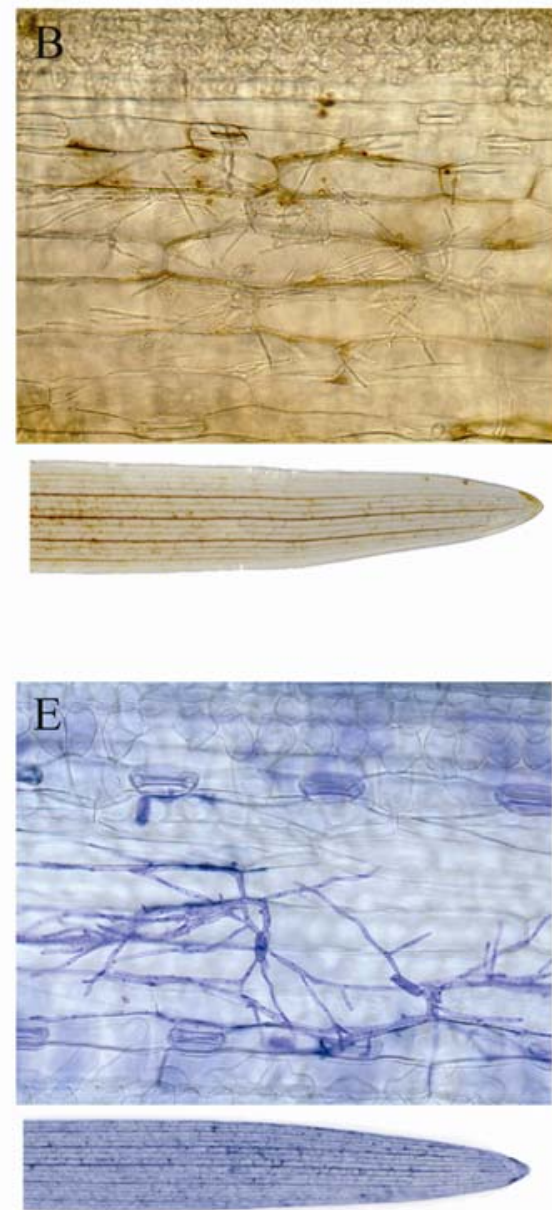

roml
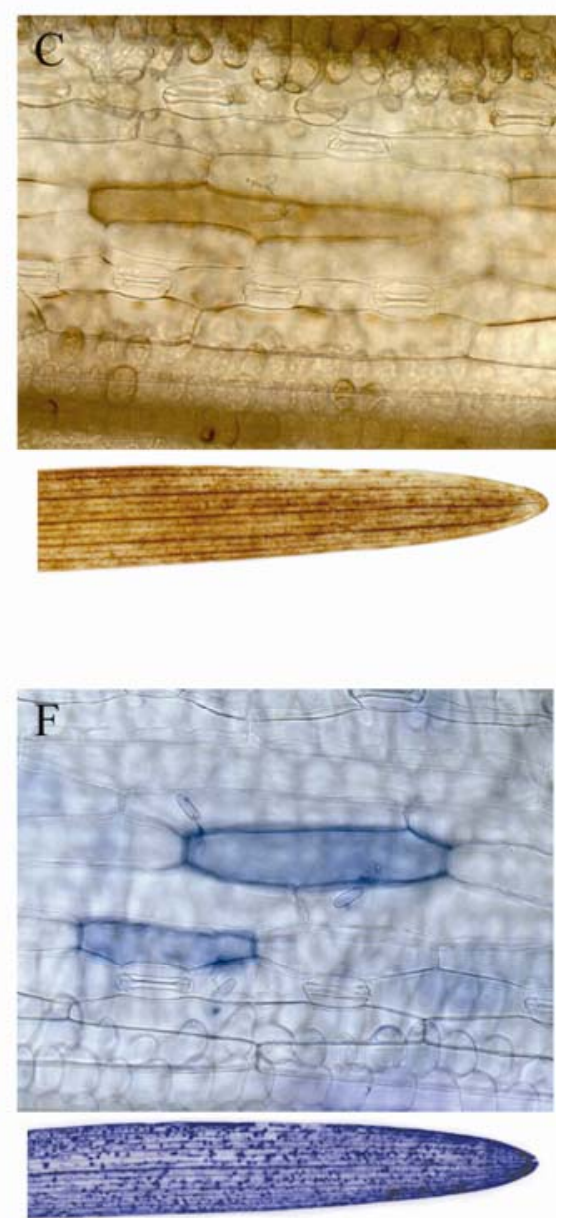

Fig. 2. Oxidative burst and cell death during powdery mildew attack. Accumulation of hydrogen peroxide monitored by $3,3^{\prime}$-diaminobenzidine staining in epidermal cells 48 h postinfection: A, wild-type Sultan5 (WT; Mla12 Rarl Rom1), B, rarl-2 mutant (Mlal2 rarl-2 Rom1), and C, rom1 mutant (Mla12 rarl-2 rom 1). Retention of trypan blue in epidermal cells indicative for a cell death reaction 72 h postinfection: D, wild-type Sultan5, E, rarl-2 mutant, and F, roml mutant. Scale bar $=100 \mu \mathrm{m}$. 
ces orontii, which causes disease only on dicot plants and for which barley is a nonhost (not shown). Collectively, this shows that Rarl and Roml are active in both race-specific and nonhost interactions of barley with powdery mildews.

\section{Unaltered RAR1 and SGT1 protein abundance in the rom 1 mutant.}

The rarl-2 allele is mutated in an invariant nucleotide within the $3^{\prime}$ splice site consensus sequence of intron 2 leading to undetectable RAR1 protein levels in Western blot analyses (Azevedo et al. 2002; Shirasu et al. 1999); therefore, we tested whether the roml infection phenotype is due to restored RAR1 protein accumulation. Protein extracts from the wild type, rarl-2, and rom 1 mutant were separated by sodium dodecyl sulfate polyacrylamide gel electrophoresis and probed with an RAR1-specific antibody (Fig. 5). The approximately $30-\mathrm{kDa}$ RAR1 protein was detected in the wild-type but absent in both the rarl-2 and roml mutant genotypes. In addition, we examined the abundance of the RAR1 interacting protein SGT1 (approximately $45 \mathrm{kDa}$ ) which was unaltered in both mutant genotypes compared with the wild type.
Genetic analyses of the rom 1 mutant.

In order to determine the inheritance of the novel infection phenotype in the rom 1 mutant 348/1a, rom1 plants were crossed with several barley lines containing the Mlal2 resistance gene. The $\mathrm{F}_{2}$ populations were inoculated with isolate A6 and scored for the outcome of the interaction (Table 1).

The segregation in the backcross with the rarl-2 mutant (M100) showed that the inheritance of the roml infection phenotype (mutant 348/1a) is consistent with a monogenic recessive trait $(P>0.95)$. This result was confirmed in the cross with the rarl-1 mutant M82 $(P>0.3)$. Thus, the roml locus is able to restore features of Mla12-triggered race-specific resistance independent from the rarl mutant allele. In $\mathrm{F}_{2}$ populations derived from crosses with barley wild-type genotypes Sultan 5 and Nudinka, segregation of the rom 1 infection phenotype did not fit the expected 12:3:1 ratio $(P<0.05)$ for two unlinked loci (Rarl and Rom1). However, the data were all in accordance with a 3:1 segregation of wild-type to mutant plants (rarl-2 and roml mutant infection phenotypes taken together). These results suggested linkage between the rarl-2 mutant allele and the rom 1 locus. Therefore, we performed an

\section{WT}
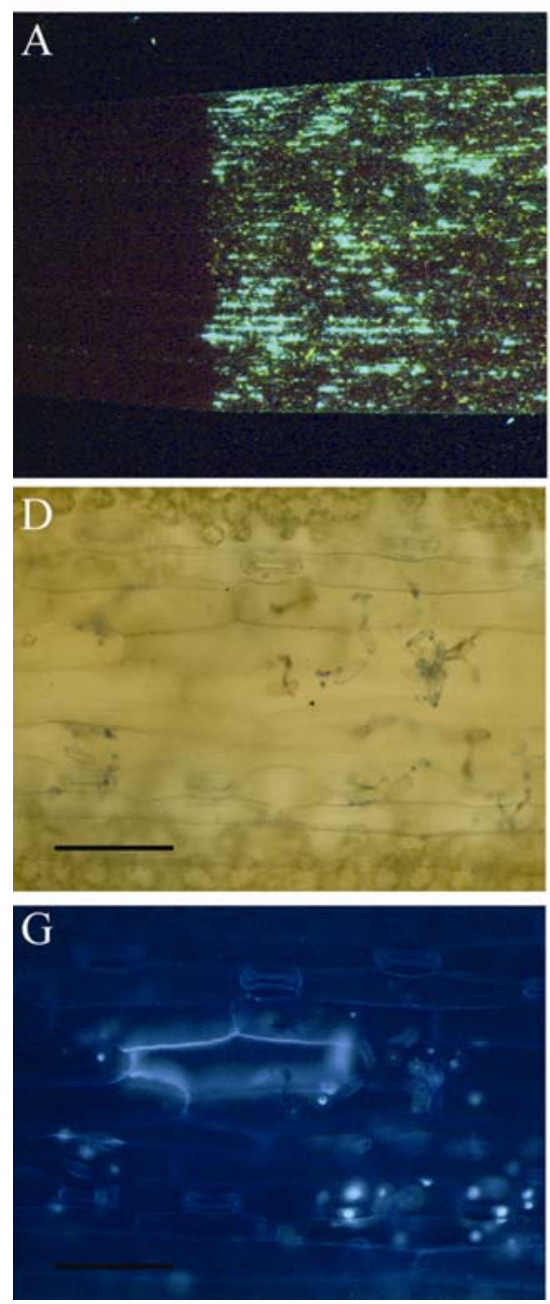

$\operatorname{rarl} 1-2$
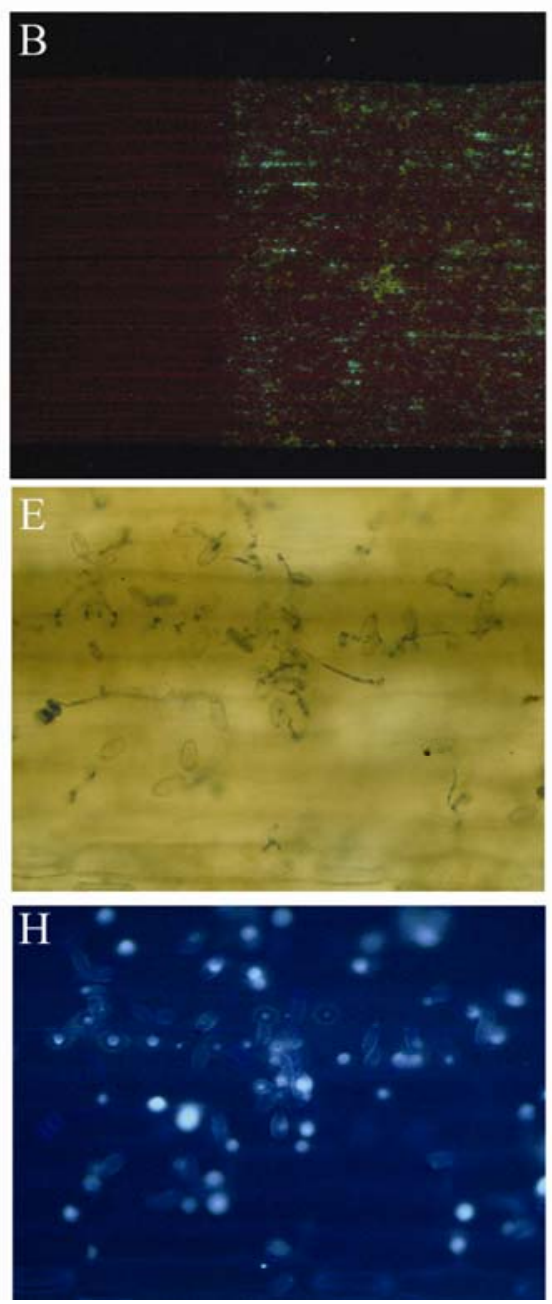

rom 1
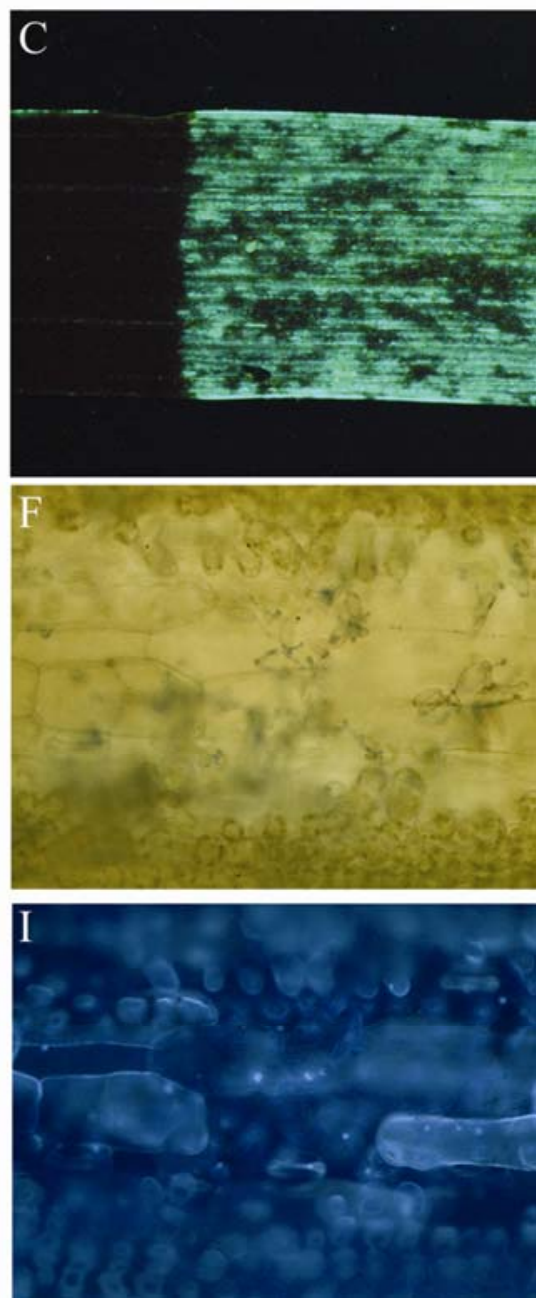

Fig. 4. Resistance response triggered by infection with Blumeria graminis f. sp. tritici. A through $\mathbf{C}$, The right half of the barley leaf was inoculated with tritici powdery mildew isolate JIW28 and inspected 5 days later for autofluorescent cells under UV light with Leica filter GFP1 (425/60 nm excitation filter, 480 barrier filter). The left half of the leaf was covered with tape prior to inoculation. Magnification is $\times 5$. D tbrough $\mathbf{F}$, Infection sites under the light microscope. Fungal structures are stained by Coomassie blue. Note: no penetration into epidermal cells was detected (not shown). G through I, Same infection sites as shown in D through F under UV light. Callose deposition is visible due to aniline blue staining of the specimen. A, D, and G are wild-type Sultan5 (WT, Mla12 Rarl Roml); B, E, and H are rarl-2 mutant (Mla12 rarl-2 Roml); and C, F, and I are roml mutant (Mla12 rarl-2 roml). Scale bar $=100 \mu \mathrm{m}$. 
amplified fragment length polymorphism (AFLP) mapping approach (Becker et al. 1995, Castiglioni et al. 1998) on $F_{2}$ segregants of the cross with cv. Nudinka by taking advantage of AFLP markers known to map on chromosome 2H (Rarl location) and assigned the chromosomal map position of Roml (Fig. 6). The Roml locus co-segregated in all 17 tested roml mutant plants with AFLP marker E4044-5 (34 chromosomes). Tested rarl mutants showed at least one recombinant chromosome for marker E4044-5 (23 recombinant chromosomes out of 42; 21 rarl-2 mutant plants tested). AFLP marker E3546-13 was positioned distal from Roml (1 recombinant chromosome out of 34).

\section{DISCUSSION}

We provide genetic, molecular, and histochemical data that we have identified a locus, Roml, which negatively affects an RAR1-dependent race-specific resistance response in barley. The finding that both Rarl and Roml also are required for defense responses triggered by inappropriate powdery mildews of barley extends the number of common components in racespecific and nonhost resistance reactions. RAR1 dependency in race-specific resistance is a widespread phenomenon in different pathogen classes in diverse plant species (tobacco, Arabidopsis, barley) (Shirasu and Schulze-Lefert 2003); therefore, the rom 1 mutant broadens our knowledge about the regulation of plant immunity.

\section{Restoration of $\mathrm{H}_{2} \mathrm{O}_{2}$ accumulation as a trigger of cell death?}

The accumulation of hydrogen peroxide in barley upon powdery mildew attack occurs in a timely and spatially regulated manner and, on this basis, can be divided into three phases (Hückelhoven and Kogel 2003). The first and second phases are characterized by spatially restricted hydrogen peroxide accumulation (i) beneath the primary fungal germ tube and (ii) beneath the fungal appressorium. In the third phase, hydrogen peroxide accumulation is no longer restricted to subcellular compartments but occurs throughout the whole attacked cell. Accumulation of hydrogen peroxide beneath the primary germ tube and the fungal appressorium was not altered in Rarl or Roml mutants in our studies (first phase,
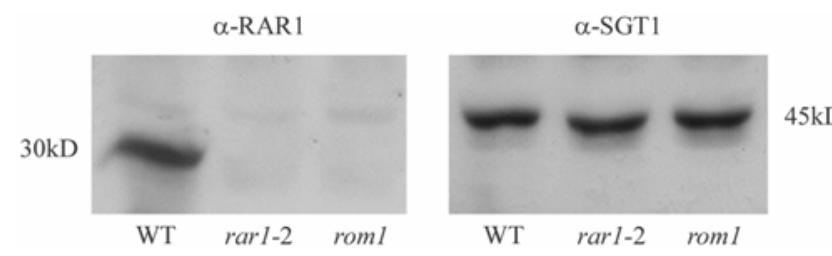

Fig. 5. Protein abundance of RAR1 and SGT1 in wild-type and mutant plants. Western blots were probed with RAR1- $(\alpha-$ RAR1) or SGT1- $(\alpha-$ SGT1) specific antibody. Protein extracts were from uninoculated leaf tissue of wild-type Sultan5 (WT; Mla12 Rarl Rom1), rarl-2 mutant (Mla12 rarl-2 Rom1), and rom1 mutant (Mla12 $\mathrm{rarl}-2 \mathrm{rom} 1$ ). not shown; second phase, Fig. 2). However, whole-cell hydrogen peroxide accumulation of attacked host cells was dramatically decreased in rarl mutant plants and restored to wild-type-like frequency in the rom 1 mutant plants. Wholecell accumulation of reactive oxygen intermediates is known to be closely linked with the onset of a subsequent cell death reaction in Mla-triggered race-specific resistance (Shirasu et al. 1999; Thordal-Christensen et al. 1997). Indeed, our dye exclusion assay with trypan blue clearly showed that the restoration of this response coincides with the restoration of pathogen-triggered cell death in rom 1 mutants (Fig. 2E). We hypothesize that the roml mutant identifies a locus which negatively affects the outcome of a Rarl-dependent race-specific resistance response.

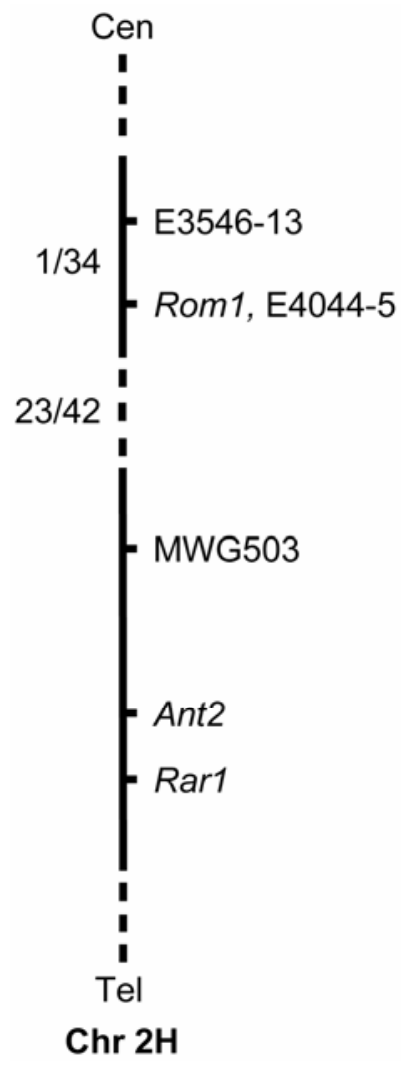

Fig. 6. Map position of the barley Roml locus. Based on the analyses of $\mathrm{F}_{2}$ plants segregating for the rarl-2 and rom 1 mutant infection phenotype, the Rom1 locus could be positioned on chromosome $2 \mathrm{H}$ of barley. Amplified fragment length polymorphism (AFLP) marker E4044-5 co-segregated with all 17 rom 1 mutant plants tested. All 21 plants being scored as rarl mutant were recombinant for AFLP marker E4044-5 (23 recombinant chromosomes out of 42). AFLP marker E3546-13 is separated by a single recombination event from the Roml locus (1 recombinant chromosome out of 34). MWG503 is a restricted fragment length polymorphism marker; Ant $2=$ anthocyanin locus 2 . Note that spaces between markers do not represent defined physical distances.

Table 1. Phenotypes and segregation ratios from crosses of the rom 1 mutant 348/1a with different Mla12-containing barley lines

\begin{tabular}{|c|c|c|c|c|c|c|}
\hline \multirow[b]{2}{*}{ Cross 348/1a (rar1-2 roml) } & \multicolumn{3}{|c|}{$F_{2}$ infection phenotype } & \multirow[b]{2}{*}{ Ratio } & \multirow[b]{2}{*}{$\chi^{2}$ for segregation } & \multirow[b]{2}{*}{$P$} \\
\hline & Wild type (Rar1 Rom1) & M100/M82 (rar1 Rom1) & 348/1a (rarl-2 roml) & & & \\
\hline × M100 $(\operatorname{rarl}-2$ Rom1 $)$ & 0 & 82 & 27 & $3: 1$ & 0.0031 & $>0.95$ \\
\hline$\times$ M82 (rarl-1 Roml $)$ & 0 & 33 & 14 & $3: 1$ & 0.5763 & $>0.3$ \\
\hline$x$ & 223 & 35 & 23 & $12: 3: 1$ & 8.333 & $<0.02$ \\
\hline Sultan5 (Rar1 Rom1) & 223 & \multicolumn{2}{|c|}{58} & $3: 1$ & 2.848 & $>0.05$ \\
\hline$x$ & 124 & \multirow[t]{2}{*}{19} & 19 & $12: 3: 1$ & 12.09 & $<0.01$ \\
\hline Nudinka (Rarl Rom1) & 124 & & & $3: 1$ & 0.206 & $>0.5$ \\
\hline
\end{tabular}


An exaggerated cell death response appears

to be the consequence

of deregulated resistance in rom1 plants.

A hallmark of cell death in the context of race-specific resistance is the spatial confinement to a few cells at sites of attempted infection. The strong necrotic phenotype of roml mutant plants upon powdery mildew infection is suggestive of a deregulation of the resistance response, as has been described for the Arabidopsis lsdl mutant (Jabs et al. 1996). However, the rom 1 mutant is not a typical lesion mimic mutant because we did not observe necrosis spreading into unchallenged tissue (Fig. 1E). The observed infection phenotype of roml mutants might be due to a delayed defense response which supports fungal escapes and, thus, increases the amount of cell death and necrotic tissue. This might reflect the situation observed in Arabidopsis rarl mutant plants impaired in RPP5-triggered resistance to Peronospora parasitica. The growing mycelium is followed by a trailing necrosis indicative of a delayed RPP5-mediated HR response in these plants (Muskett et al. 2002). In our analysis of the roml mutant (Fig. 2), we observed, in most cases, halt of fungal growth prior to ramification of fungal hyphae. Therefore, in the rom 1 mutant, the severity of the resistance response appears higher than in the wild type. Exposure of roml and Roml leaves to different dosages of paraquat, which is known to provoke a light-inducible oxidative damage in plant cells leading to cell death (Dodge 1971), did not reveal significant differences between the genotypes (not shown). Similar results were obtained upon treatment with Rose Bengal, known to induce oxidative stress by the production of singlet oxygen (Affek and Yakir 2002; not shown). This suggests that the rom 1 mutant is not generally impaired in the responsiveness to oxidative stress.

Restoration of the resistance response in roml plants also could be the consequence of constitutive activation of pathogenesis-related $(P R)$ genes (Lorrain et al. 2003). However, absence of spontaneous necrosis, absence of constitutive $P R-1$ gene expression in unchallenged roml plants (not shown), and retained susceptibility to virulent $B$. graminis f. sp. hordei and Puccinia hordei isolates suggests that roml plants are fundamentally different from previously described Arabidopsis cpr mutants that show a constitutive expression of defense-related genes (Bowling et al. 1994, 1997; Jirage et al. 2001). Likewise, retained susceptibility to the virulent $B$. graminis $\mathrm{f}$. $\mathrm{sp}$. hordei isolate distinguishes the roml mutant from Arabidopsis pmr and $e d r l$ mutants that exhibit enhanced disease resistance to virulent Erysiphe cichoracearum (Frye et al. 2001; Vogel and Somerville 2000).

\section{Rar1 and Rom1: A link \\ between nonhost and race-specific resistance?}

Challenge inoculation with conidiospores of a wheat and a dicot-infecting powdery mildew species resulted in whole-cell autofluorescence and callose accumulation, both being indicative of induced defense responses. A similar whole-cell autofluorescence has been described upon inoculation of $B$. graminis f. sp. hordei spores on the nonhost Arabidopsis in cases where the fungus was able to penetrate into attacked epidermal cells (Collins et al. 2003). Our analysis revealed that whole-cell autofluorescence is strongly diminished in an rarl background whereas the rarl roml genotype showed not only a restored but even an enhanced fluorescence reaction compared with wild-type plants. This indicates that both Rarl and Roml participate in nonhost reactions to the inappropriate powdery mildews (Fig. 4). The exaggerated response in the rom $1 \mathrm{mu}-$ tant is consistent with the proposed negative activity of the Roml wild-type locus in disease resistance. To date, Rarl has been shown to be required for a subset of race-specific resis- tance responses mediated by intracellular NB-LRR type R proteins (Holt et al. 2003; Shirasu and Schulze-Lefert 2003). Our findings suggest that Rarl also is required for nonhost interactions of barley. However, the rarl mutation on its own was not sufficient to support enhanced growth of the inappropriate fungi. The latter could be explained by unaffected penetration resistance that is under control of barley Ror and Arabidopsis PEN genes (Collins et al. 2003; Peterhänsel et al. 1997). If NB-LRR R proteins participate in nonhost resistance to powdery mildew fungi, it is conceivable that the diminished autofluorescence response in rarl plants reflects impaired recognition of conserved powdery mildew effectors that are present in $B$. graminis f. sp. hordei, B. graminis f. sp. tritici, and G. orontii. Interestingly, a function for the RAR1 interactor SGT1 in nonhost resistance has been shown in $N$. benthamiana interactions with inappropriate Xanthomonas spp. (Peart et al. 2002).

Plants have the capacity to recognize isolate-specific effectors and conserved pathogen-associated molecular patterns (PAMPs). Recognition of both types of molecules by receptors elicits immune responses that can include MAP kinase signaling and induction of defense-related genes (Asai et al. 2002; Jin et al. 2002). However, resistance in Arabidopsis to Pseudomonas syringae induced by the PAMP flg22, a flagellinderived peptide that is recognized by the membrane resident receptor FLS2 (Gómez-Gómez and Boller 2000), does not require tested signaling components known to be involved in $R$ gene-triggered resistance such as EDS1, RAR1, or SGT1 (Zipfel et al. 2004). In addition, flg22, like many other PAMPs, does not provoke a cellular suicide of plant cells, demonstrating that $R$-gene- and PAMP-receptor-triggered immune responses are at least partially dissimilar (Asai et al. 2002; Gómez-Gómez and Boller 2002; Nürnberger et al. 2004). If lack of cell death in PAMP-mediated resistance involves negative regulation, the exaggerated resistance response in roml plants might reflect a potentiated PAMP-triggered response in which cell death suppression is impaired. Recently, virulent but not inappropriate powdery mildews have been shown to suppress plant defense responses in Arabidopsis (Zimmerli et al. 2004). This finding could explain retained susceptibility in rom 1 mutants to the virulent $B$. graminis $\mathrm{f}$. $\mathrm{sp}$. hordei isolate. Future studies should reveal whether the Roml wild-type locus controls yet unknown cross-talk between PAMP-triggered and race-specific plant immunity.

\section{MATERIALS AND METHODS}

\section{Plant material, mutagenesis, and seedling inoculations.}

The rarl mutant plants M82 and M100 were derived from the double-haploid barley line Sultan5 (Torp and Jørgensen 1986). Cv. Nudinka was used to establish a general AFLP map of barley (Becker et al. 1995) and contained the Mla12 resistance gene. Crosses were performed by pollination of mutant 348/1a with pollen derived from barley lines indicated in Table 1. Chemical mutagenesis with $\mathrm{NaN}_{3}$ and tests for resistance using different powdery mildew isolates were described previously (Freialdenhoven et al. 1994, 1996). The frequency of chlorophyll-defective $\mathrm{M}_{2}$ seedlings $(6 \%)$ and the parallel isolation of two independent mlo mutant plants in the population ( $m l o-29)$ (Piffanelli et al. 2002) indicated that the mutation rate was in the general range for chemical mutagenesis of barley (Jende-Strid 1978).

\section{Histochemical analysis} and single-cell transient expression assay.

Uptake and polymerization of DAB (Sigma, St. Louis) was monitored according to the protocol of Thordal-Christensen and associates (1997). Trypan blue retention was carried out as 
described by Peterhänsel and associates (1997). Staining for callose was performed with $0.01 \%$ aniline blue (wt/vol) (Sigma-Aldrich) in $150 \mathrm{mM} \mathrm{KH}_{2} \mathrm{PO}_{4}$ (pH 9.5) for $48 \mathrm{~h}$. Microscopic inspection of specimens was conducted as described previously (Peterhänsel et al. 1997). For the single-cell transient expression assays, the protocol and over-expression constructs described by Shen and associates (2003) were used. Each bar in Figure 3 is the result of at least three independent shooting experiments and a minimum of 150 single-cell interaction sites.

\section{Molecular analysis.}

RAR1 and SGT1 protein detection are described in Azevedo and associates (2002). For each genotype, a protein mixture of five independent primary leaves was used for the Western blot shown in Figure 5. DNA from single $\mathrm{F}_{2}$ plants was isolated for AFLP analysis which was performed as described by Becker and associates (1995). The $F_{2}$ infection phenotypes were confirmed by inoculation experiments of derived $\mathrm{F}_{3}$ segregants. AFLP and restriction fragment length polymorphism marker designations are according to Castiglioni and associates (1998) and Graner and associates (1991), respectively.

\section{ACKNOWLEDGMENTS}

We thank C. Dawidson for excellent care of plant material, S. Effgen for technical assistance during the AFLP mapping approach, and C. Vincent for her assistance in figure preparation and critical comments to the manuscript.

\section{LITERATURE CITED}

Aarts, N., Metz, M., Holub, E., Staskawicz, B., Daniels, M., and Parker, J. E. 1998. Different requirements for EDS1 and NDR1 by disease resistance genes define at least two $R$ gene-mediated signaling pathways in Arabidopsis. Proc. Natl. Acad. Sci. U.S.A. 95:10306-10311.

Affek, H. P., and Yakir, D. 2002. Protection by isoprene against singlet oxygen in leaves. Plant Physiol. 129:269-277.

Asai, T., Tena, G., Plotnikova, J., Willmann, M. R., Chiu, W. L., GómezGómez, L., Boller, T., Ausubel F., and Sheen, J. 2002. A MAP kinase signaling cascade in Arabidopsis innate immunity. Nature 415:977-983.

Azevedo, C., Sadanandom, A., Kitigawa, K., Freialdenhoven, A., Shirasu, K., and Schulze-Lefert, P. 2002. The RAR1 interactor SGT1 is an essential component of $R$-gene triggered disease resistance. Science 295:2073-2076.

Becker, J., Vos, P., Kuiper, M., Salamini, F., and Heun, M. 1995. Combined mapping of AFLP and RFLP markers in barley. Mol. Gen. Genet. 249:65-73.

Bonas, U., and Lahaye, T 2002. Plant disease resistance triggered by pathogen-derived molecules: refined models of specific recognition. Curr. Opin. Microbiol. 5:44-50.

Bowling, S. A., Guo, A., Cao, H., Gordon, A. S., Klessig, D. F., and Dong, X. 1994. A mutation in Arabidopsis that leads to constitutive expression of systemic acquired resistance. Plant Cell 6:1845-1857.

Bowling, S. A., Clarke, J. D., Liu, Y., Klessig, D., and Dong, X. 1997. The cpr5 mutant of Arabidopsis expresses both NPR1-dependent and NPR1-independent resistance. Plant Cell 9:1573-1584.

Boyd, L. A., Smith, P. H., Foster, E. M., and Brown, J. K. M. 1995. The effects of allelic variation at the Mla resistance locus in barley on the early development of Erysiphe graminis f. sp. hordei and host responses. Plant J. 7:959-968.

Büschges, R., Hollricher, K., Panstruga, R., Simons, G., Wolter, M., Frijters, A., van Daelen, R., van der Lee, T., Diergaarde, P. Groenendijk, J., Töpsch, S., Vos, P., Salamini, F., and Schulze-Lefert, P. 1997. The barley Mlo gene: a novel control element of plant pathogen resistance. Cell 88:695-705.

Castiglioni P., Pozzi, C., Heun, M., Terzi, V., Müller, K. J., Rohde, W., and Salamini, F. 1998. An AFLP-based procedure for the efficient mapping of mutations and DNA probes in barley. Genetics 149:2039-2056.

Century, K. S., Shapiro, A. D., Repetti, P. P., Dahlbeck, D., Holub, E., and Staskawicz, B. J. 1997. NDR1, a pathogen-induced component required for Arabidopsis disease resistance. Science 278:1963-1965.

Collins, N. C., Thordal-Christensen, H., Lipka, V., Bau, S., Kombrink, E., Qiu, J., Hückelhoven, R., Stein, M., Freialdenhoven, A., Somerville, S., and Schulze-Lefert, P. 2003. SNARE-protein-mediated disease resistance at the plant cell wall. Nature 425:973-977.

Dangl, J. L., and Jones, J. D. G. 2001. Plant pathogens and integrated defence responses to infection. Nature 411:826-833.

Dodge, A. D. 1971. The mode of action of the bipyridylium herbicides, paraquat and diquat. Endeavour 30:130-135.

Falk, A., Feys, B. J., Frost, L. N., Jones, J. D. G., Daniels, M. J., and Parker, J. E. 1999. EDS1, an essential component of $R$ gene-mediated disease resistance in Arabidopsis has homology to eukaryotic lipases. Proc. Natl. Acad. Sci. U.S.A. 96:3292-3297.

Flor, H. H. 1971. Current status of the gene-for-gene concept. Annu. Rev. Phytopathol. 9:275-296.

Freialdenhoven, A., Scherag, B., Hollricher, K., Collinge, D., Christensen, H. T., and Schulze-Lefert, P. 1994. Nar-1 and Nar-2, two loci required for Mla12-specified race-specific resistance to powdery mildew in barley. Plant Cell 6:983-994.

Freialdenhoven, A., Peterhänsel, C., Kurth, J., Kreuzaler, F., and SchulzeLefert, P. 1996. Identification of genes required for the function of nonrace-specific mlo resistance to powdery mildew. Plant Cell 8:5-14.

Frye, C. A., Tang, D., and Innes, R. W. 2001. Negative regulation of defense responses in plants by a conserved MAPKK kinase. Proc. Natl. Acad. Sci. U.S.A. 98:373-378.

Gómez-Gómez, L., and Boller, T. 2000. FLS2: an LRR receptor-like kinase involved in the perception of the bacterial elicitor flagellin in Arabidopsis. Mol. Cell 5:1003-1011.

Gómez-Gómez, L., and Boller, T. 2002. Flagellin perception: a paradigm for innate immunity. Trends Plant Sci. 7:251-256.

Graner, A., Jahoor, A., Schondelmaier, J., Siedler, H., Pillen, K. Fischbeck, K., Wenzel, G., and Herrmann, R. G. 1991. Construction of an RFLP map of barley. Theor. Appl. Genet. 83:250-256.

Halterman, D. A., and Wise R. P. 2004. A single-amino acid substitution in the sixth leucine-rich repeat of barley MLA6 and MLA13 alleviates dependence on RAR1 for disease resistance signaling. Plant J. 38:215-226.

Halterman, D., Zhou, F., Wei, F., Wise, R. P., and Schulze-Lefert, P. 2001. The Mla6 coiled-coil, NBS-LRR protein confers AvrMla6-dependent resistance specificity to Blumeria graminis f. sp. hordei in barley and wheat. Plant J. 25:335-348.

Hammond-Kosack, K. E., Jones, D. A., and Jones, J. D. G. 1994. Identification of two genes required for full $C f$-9-dependent resistance to Cladosporium fulvum. Plant Cell 6:361-374.

Holt, B. F., Hubert, D. A., and Dangl, J. L. 2003. Resistance gene signaling in plants-complex similarities to animal innate immunity. Curr. Opin. Immunol. 15:20-25.

Hubert, D. A., Tornero, P., Belkhadir, Y., Krishna, P., Takahashi, A., Shirasu, K., and Dangl, J. L. 2003. Cytosolic HSP90 associates with and modulates the Arabidopsis RPM1 disease resistance protein. EMBO (Eur. Mol. Biol. Organ.) J. 22:5679-5689.

Hückelhoven, R., and Kogel, K. H. 2003. Reactive oxygen intermediates in plant-microbe interactions: who is who in powdery mildew resistance? Planta 216:891-902.

Jabs, T., Dietrich, R. A., and Dangl, J. L. 1996. Initiation of runaway cell death in an Arabidopsis mutant by extracellular superoxide. Science 273:1853-1856.

Jende-Strid, B. 1978. Mutation frequencies obtained after sodium azide treatment in different barley varieties. Barley Genet. Newsl. 8:55-57.

Jin, H., Axtell, M. J., Dahlbeck, D., Ekwenna, O., Zhang, S., Staskawicz, B., and Baker, B. 2002. NPK1, an MEKK-1 like mitogen-activated protein kinase kinase kinase, regulates innate immunity and development in plants. Develop. Cell 3:1-20.

Jirage, D., Zhou, N., Cooper, B., Clarke, J. D., Dong, X., and Glazebrook, J. 2001. Constitutive salicylic acid-dependent signaling in cprl and cpr6 mutants requires PAD4. Plant J. 26:395-407.

Jørgenson, J. H. 1994. Genetics of powdery mildew resistance in barley. Crit. Rev. Plant Sci. 13:97-119.

Jørgenson, J. H. 1996. Effect of three suppressors on the expression of powdery mildew resistance genes in barley. Genome 39:492-498.

Kang, L., Li, J. X., Zhao, T. H., Xiao, F. M., Tang, X. Y., Thilmony, R, He, S. Y., and Zhou, J. M. 2003 Interplay of the Arabidopsis nonhost resistance gene $\mathrm{NHO1}$ with bacterial virulence. Proc. Natl. Acad. Sci. U.S.A. 100:3519-3524.

Kanzaki, H., Saitoh, H., Ito, A., Fujisawa, S., Kamoun, S., Katou, S., Yoshioka, H., and Terauchi, R. 2003. Cytosolic HSP90 and HSP70 are essential components of INF1-mediated hypersensitive response and non-host resistance to Pseudomonas cichorii in Nicotiana benthamiana. Mol. Plant Pathol. 4:383-391.

Koegh, R. C., Deverall, B. J., and McLeod, S. 1980. Comparison of histological and physiological responses to Phakopsora pachyrhizi in resistant and susceptible soybean. Trans. Br. Mycol. Soc. 74:329-333.

Lahaye, T., Shirasu, K., and Schulze-Lefert, P. 1998. Chromosome landing at the barley Rar1 locus. Mol. Gen. Genet. 260:92-101. 
Liu, Y., Burch-Smith, T., Schiff, M., Feng, S., and Dinesh-Kumar, S. P. 2004. Molecular chaperone Hsp90 associates with resistance protein N and its signaling proteins SGT1 and Rar1 to modulate an innate immune response in plants. J. Biol. Chem. 279:2101-2108.

Lorrain, S., Vailleau, F., Balagué, C., and Roby, D. 2003. Lesion mimic mutants: keys for deciphering cell death and defense pathways in plants? Trends Plant. Sci. 8:263-271.

Muskett, P. R., Kahn, K., Austin, M. J., Moisan, L. J., Sadanandom, A., Shirasu, K., Jones, J. D. G., and Parker, J. E. 2002. Arabidopsis RARI exerts rate-limiting control of $R$ gene-mediated defenses against multiple pathogens. Plant Cell 14:979-992.

Mysore, K. S., and Ryu, C. M. 2004. Nonhost resistance: how much do we know? Trends Plant Sci. 9:97-104.

Nürnberger, T., Brunner, F., Kemmerling, B., and Piater, L. 2004. Innate immunity in plants and animals: striking similarities and obvious differences. Immunol. Rev. 198:249-266.

Peart, J. R., Lu, R., Sadanandom, A., Malcui, I., Moffett, P., Brice, D. C, Schauser, L., Jaggard, D. A., Xiao, S., Coleman, M. J., Dow, M., Jones, J. D., Shirasu, K., and Baulcombe, D. C. 2002. Ubiquitin ligase-associated protein SGT1 is required for host and nonhost disease resistance in plants. Proc. Natl. Acad. Sci. U.S.A. 99:10865-10869.

Peterhänsel, C., Freialdenhoven, A., Kurth, J., Kolsch, R., and SchulzeLefert P. 1997. Interaction analysis of genes required for resistance responses to powdery mildew in barley reveal distinct pathways leading to leaf cell death. Plant Cell 9:1397-1409.

Piffanelli, P., Zhou, F., Casais, C., Orme, J., Schaffrath, U., Collins, N., Panstruga, R., and Schulze-Lefert, P. 2002. The barley MLO modulator of defence and cell death is responsive to biotic and abiotic stimuli. Plant Physiol. 129:1076-1085.

Salmeron, J. M., Barker, S. J., Carland, F. M., Mehta, A. Y., and Staskawicz, B. J. 1994. Tomato mutants altered in bacterial disease resistance provide evidence for a new locus controlling pathogen recognition. Plant Cell 6:511-520.

Shen, Q., Zhou, F., Bieri, S., Haizel, T., Shirasu, K., and Schulze-Lefert, P. 2003. Recognition specificity and RAR1/SGT1 dependence in barley Mla disease resistance genes to the powdery mildew fungus. Plant Cell 15:732-744.

Shirasu, K., Lahaye, T., Tan, M., Zhou, F., Azevedo, C., and Schulze-
Lefert, P. 1999. A novel class of zinc-binding proteins is required for disease resistance signaling in barley and development in C. elegans. Cell 99:355-366.

Shirasu, K., and Schulze-Lefert, P. 2003. Complex formation, promiscuity, and multi-functionality: protein interactions in disease resistance pathways. Trends Plant Sci. 8:252-258.

Takahashi, A., Casais, C., Ichimura, K., and Shirasu, K. 2003. HSP90 interacts with RAR1 and SGT1 and is essential for RPS2-mediated disease resistance in Arabidopsis. Proc. Natl. Acad. Sci. U.S.A. 100:1177711782.

Thordal-Christensen, H., Zhang, Z., Wei, Y., and Collinge, D. B. 1997. Subcellular localization of $\mathrm{H}_{2} \mathrm{O}_{2}$ in plants. $\mathrm{H}_{2} \mathrm{O}_{2}$ accumulation in papillae and hypersensitive response during the barley-powdery mildew interaction. Plant J. 11:1187-1194.

Tornero, P., Merritt, P., Sadanandom, A., Shirasu, K., Innes, R. W., and Dangl, J. L. 2002. RAR 1 and NDR1 contribute quantitatively to disease resistance in Arabidopsis, and their relative contributions are dependent on the $R$-gene assayed. Plant Cell 14:1005-1015.

Torp, J., and Jørgenson, J. H. 1986. Modification of barley powdery mildew resistance gene $M l a_{12}$ by induced mutation. Can. J. Genet. Cytol. 28:725-731.

Vogel, J., and Somerville, S. 2000. Isolation and characterization of powdery mildew-resistant Arabidopsis mutants. Proc. Natl. Acad. Sci. U.S.A. 97:1897-1902.

Wei, F., Wing, R. A., and Wise, R. P. 2002. Genome dynamics and evolution of the Mla (powdery mildew) resistance locus in barley. Plant Cell 14:1903-1917.

Zhou, F., Kurth, J., Wei, F., Elliott, C., Valè, G., Yahiaoui, N., Keller, B. Somerville, S., Wise, R., and Schulze-Lefert, P. 2001. Cell-autonomous expression of barley Mlal confers race-specific resistance to the powdery mildew fungus via a Rarl-independent signaling pathway. Plant Cell 13:337-350.

Zimmerli, L., Stein, M., Lipka, V., Schulze-Lefert, P., and Somerville, S. 2004. Host and non-host pathogens elicit different jasmonate/ethylene responses in Arabidopsis. Plant J. 40:633-646.

Zipfel, C., Robatzek, S., Navarro, L., Oakeley, E. J., Jones, J. D., Felix, G., and Boller, T. 2004. Bacterial disease resistance in Arabidopsis through flagellin perception. Nature 15:764-767. 